\title{
Adverse childhood experiences. Knowledge and use by pediatrics residents
}

\author{
Abigail Casas-Muñoz, ${ }^{*}$ Arturo Loredo-Abdalá, ${ }^{1}$ Betsabé Sotres-Velasco, ${ }^{2}$ Leslie V. Ramírez-Angoa, ${ }^{3}$ \\ Juan A. Román-Olmos ${ }^{1}$ and Giancarlo H. Cristerna-Tarrasa ${ }^{3}$ \\ ${ }^{1}$ Coordination of Advanced Studies on Child Abuse-Prevention, Instituto Nacional de Pediatría; ${ }^{2}$ Faculty of Sciences, Universidad Nacional Autónoma \\ de México; ${ }^{3}$ Teaching Director's Office, Instituto Nacional de Pediatría. Mexico City, Mexico
}

\begin{abstract}
Introduction: Adverse childhood experiences (ACEs) have been associated with the acquisition of risk behaviors and development of chronic and mental diseases since adolescence and in adult life. Objective: To identify the knowledge and the frequency pediatrics residents ask about ACEs with. Methods: Through an online survey sent to all resident physicians of the 2017-2018 academic year of a tertiary care children's hospital, demographic variables, knowledge, use, training and barriers to interrogate and search for ACEs were collected. Results: $21 \%$ of residents answered the survey; the majority were women (70\%), less than $5 \%$ of participants were familiar with ACEs, $31 \%$ enquired about them in parents and their children, and $71 \%$ considered having some barrier to interrogate about them. Conclusions: Participants in this study showed limited knowledge about ACEs, which had an impact on the frequency they enquired about them with in their patients and their parents; at least half had the perception that it is beyond the reach of the pediatrician to identify them.
\end{abstract}

KEY WORDS: Violence. Adverse childhood experiences. Child abuse. Health knowledge.

\section{Experiencias adversas en la infancia. Conocimiento y uso por médicos residentes de pediatría}

\section{Resumen}

Introducción: Las experiencias adversas en la infancia (EAI) se han relacionado con la adquisición de conductas de riesgo y el desarrollo de enfermedades crónicas y mentales, desde la adolescencia y en la vida adulta. Objetivo: Identificar el conocimiento y la frecuencia con la que médicos residentes de pediatría interrogan sobre las EAl. Métodos: Mediante una encuesta en línea enviada a todos los médicos residentes del año académico 2017-2018 de un hospital pediátrico de tercer nivel, se recabaron variables demográficas, del conocimiento, uso, entrenamiento y barreras para interrogar sobre EAI. Resultados: 21 \% de los residentes respondió la encuesta, la mayoría fue del sexo femenino (70 \%), menos de 5 \% de los participantes estaba familiarizado con las EAl, 31 \% interrogaba sobre ellas a los padres e hijos y 71 \% consideró que tiene alguna barrera para interrogarlas. Conclusiones: Los participantes de este estudio mostraron un conocimiento limitado sobre las EAl, lo que repercutió en la frecuencia con la que preguntaban al respecto a sus pacientes y padres; al menos la mitad tuvo la percepción que identificarlas está fuera del alcance del pediatra.

PALABRAS CLAVE: Violencia. Experiencias adversas en la infancia. Maltrato infantil. Conocimiento sobre salud. 
Categories of adverse childhood experiences (ACEs)
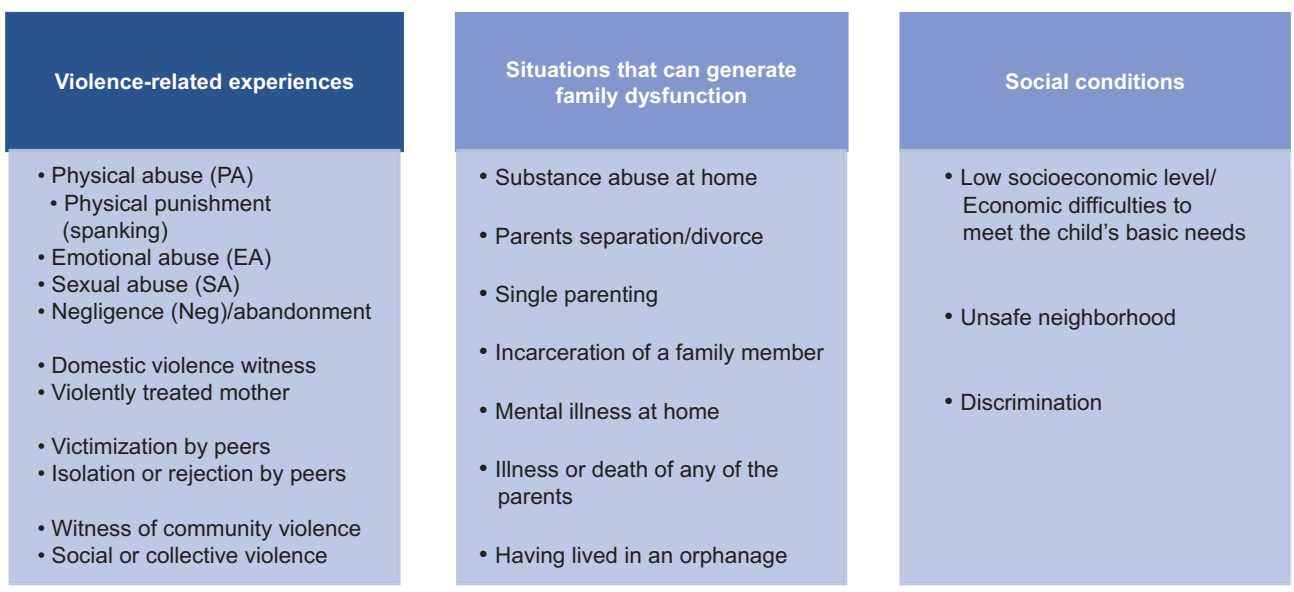

Figure 1. Categories of adverse childhood experiences ${ }^{1-4}$ (created by the authors).

\section{Introduction}

Adverse childhood experiences (ACEs) are events or continuous exposure to circumstances beyond a child's control (before 18 years of age), which can negatively affect the child's well-being. 'While some stress is normal in life, strong, frequent, or prolonged activation, and absence of the moderating protection of a relationship with an adult who supports the child generate toxic stress (TS). ACEs include three categories of TS-generating potential events (Fig. 1). Accumulation of these adversities can affect gene expression, immune system development and response to stress. ${ }^{1-3}$

ACEs can have an impact on development and overall health. They have been associated with the acquisition of risk behaviors (substance use, runaway, lack of physical activity, risky sexual behaviors and suicidal ideation) and with the development of chronic and mental illnesses (depression) since adolescence and in adult life. Therefore, pediatricians should be informed with regard to their identification and consequences. ${ }^{4-6}$

The purpose of this article was to identify the knowledge and frequency resident physicians of a tertiary care children's hospital ask about and use ACEs in their daily practice.

\section{Method}

An online survey was conducted with the www.onlineencuesta.com tool (pro version). All resident physicians who were enrolled in the different specialties and subspecialties that were taught in a tertiary care children's hospital during the 2017-2018 academic year were invited to participate.

Authorization was obtained from the American Academy of Pediatrics for using survey number 85 questions on ACEs. ${ }^{7}$ Two bilingual physicians carried out two translations of the survey and five experts on the subject reviewed and adapted the best version of each question to generate the final instrument.

Sociodemographic variables (gender, age, year of residence and university of origin) and variables of interest were collected:

1. Knowledge about ACEs.

2. ACEs background check in parents. The frequency at which residents inquired about a previous history of eleven ACEs was asked: physical abuse (PA), sexual abuse (SA), emotional abuse (EA), physical neglect (PN), emotional neglect (NE), food shortage, exposure to domestic violence (EDV), parental mental illness or substance abuse, parent or caregiver incarceration, and single parenting.

3. Search for ACEs in children, i.e., the frequency they inquired about the six main ACEs in their patients with, which were grouped as follows:

a)Those that are usually asked as part of patient personal history: separated or divorced parents, mental illness or substance abuse in parents.

b) Those that are asked with regard to knowledge about ACEs: father or mother incarceration, difficulty for covering the child's basic needs (PN, EN, food shortage) and EDV.

4. Deliberate search for child abuse (CA). Resident physicians were asked if they did a deliberate 
search to identify PA, SA, EA, PN and EN in their patients.

5. Barriers to not inquiring about ACEs. They were asked to evaluate 14 situations as barriers to inquiring about ACEs.

6. Beliefs about ACEs. The degree of agreement with eight true statements related to ACEs and their association with the development of seven diseases was asked.

7. Mental health training. Resident physicians were asked about rotations in behavioral and developmental pediatrics, child psychiatry, adolescent medicine, and behavioral sciences. Mental training was considered to exist in those who rotated more than three weeks.

\section{Statistical analysis}

Missing data were imputed using the random forest method. Frequencies and central tendency measures were calculated for sociodemographic variables. The Rao-Scott test of independence (considered significant with a $p$-value $<0.05$ ) was used to define the relationship between sociodemographic variables and variables of interest. ${ }^{8}$

By means of logistic regression, the probability (odds ratio, OR) of inquiring about ACEs and carrying out a deliberate search for CA was calculated based on the knowledge they had on the subject. The models were adjusted according to sociodemographic characteristics, beliefs about ACEs, and mental health training. For cases with high OR values (rare cases), the Firth method was used for calculation. ${ }^{9}$

Statistical analysis was carried out with RStudio software, version 1.1.423 (RStudio Inc., 2009-2018). ${ }^{10}$

\section{Ethical considerations}

Consent was requested from all participants, and they were informed on the handling and protection of their information through a privacy notice. The study was approved by the institutional research and research ethics committees (registration number 042/2017).

\section{Results}

Information from 77 surveys was analyzed (Fig. 2). Most participants were females (70\%); average age was 28 years (median, 27 years) and half the participants $(55 \%)$ came from universities of Mexico City.

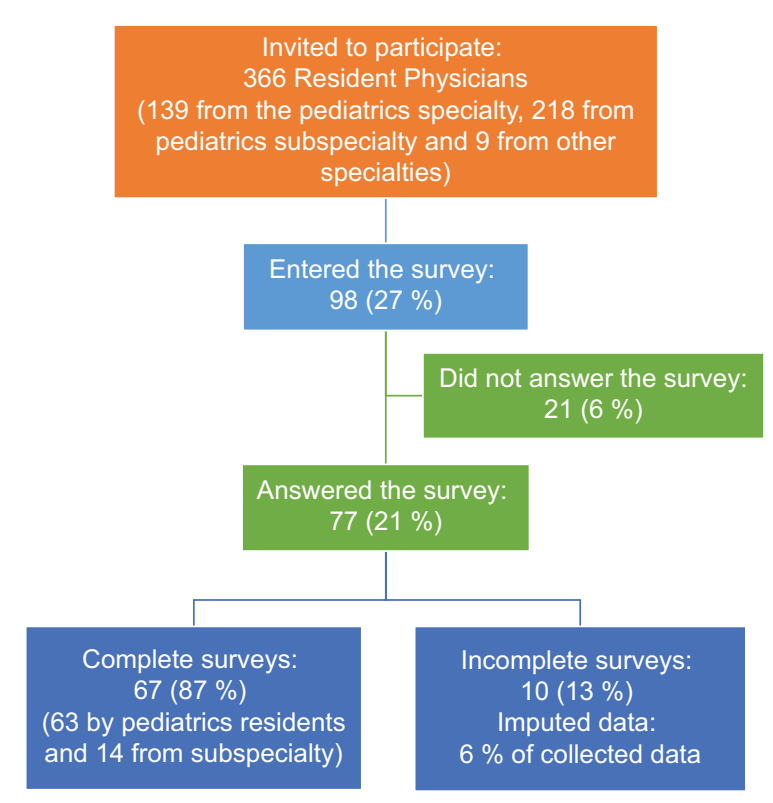

Figure 2. Diagram of participation of physicians from a tertiary care children's hospital, December 2017 to February 2018.

\section{Knowledge about ACEs}

Sixty percent of participants were not at all familiar, $38 \%$ somewhat or little familiar and only $2 \%$ considered themselves very familiar with the subject. Pediatrics residents were more familiar than subspecialty residents ( $p=<0.01) ; 18 \%$ knew any ACE; those that were reported were PA (71\%), EA (71\%), SA (50\%), neglect $(21 \%)$, abandonment (14\%), harassment (14\%), alcoholic or drug-addicted parents (7\%), dysfunctional family $(7 \%)$, parents illness or prolonged hospitalization $(7 \%)$ and death of a parent $(7 \%)$.

\section{Inquiring about history of ACEs in parents}

Seventy-four percent of residents reported to inquire about a history of ACEs in most parents: substance abuse (30\%) or mental illness $(24 \%)$ in parents, food shortage (13\%), single parenting (13\%), EDV (12\%), EA, PN and mother, father or caregiver incarceration (4\%), PA (2\%) and SA (2\%). The number of ACEs participants investigated ranged from one to three (33\%), four to six (22\%), and seven to eleven (19\%); $26 \%$ never or only sometimes did.

\section{Search for ACEs in children}

Most participants (94\%) questioned their patients about at least one ACE, and very few, about all six $(4 \%)$; one third (31\%) asked about history of ACEs 
Table 1. Resident physicians search for six adverse childhood experiences in their patients

\begin{tabular}{|c|c|c|c|c|}
\hline \multirow[t]{2}{*}{ Adverse childhood event } & \multirow{2}{*}{$\begin{array}{l}\text { Asks about it }(\%) \\
(n=77)\end{array}$} & \multicolumn{3}{|c|}{ Gender differences in those who ask (\%)* } \\
\hline & & $\begin{array}{c}\text { Do not ask } \\
\text { about it }\end{array}$ & Ask about it & p \\
\hline $\begin{array}{l}\text { 1. Separated or divorced parents } \\
\text { Female resident (70 \%) } \\
\text { Male resident (30\%) }\end{array}$ & 33.8 & $\begin{array}{c}70.4 \\
56.53\end{array}$ & $\begin{array}{c}29.6 \\
43.47\end{array}$ & $<0.01$ \\
\hline $\begin{array}{l}\text { 2. Father or mother is/was incarcerated } \\
\text { Female resident (70 \%) } \\
\text { Male resident (30\%) }\end{array}$ & 10.4 & $\begin{array}{c}92.6 \\
82.61\end{array}$ & $\begin{array}{c}7.4 \\
17.39\end{array}$ & $<0.01$ \\
\hline 3. Alcohol or drug consumption by parents & 76.6 & & & \\
\hline 4. Mother suffers or has suffered from depression or any mental illness & 27.3 & & & \\
\hline 5. Parents with economic difficulties to cover the child's basic needs & 23.4 & & & \\
\hline 6. Exposure to domestic violence & 15.6 & & & \\
\hline
\end{tabular}

in both parents and children (Table 1). Males asked more about whether the parents were separated or divorced $(p<0.01)$ and about parents or caregivers incarceration $(p<0.01)$ (Table 1). Eighty-eight percent of participants asked about previous history data that are usually recorded in the medical record, and $43 \%$, those related to knowledge about ACEs, mainly participants who were first-year pediatrics residents $(p<0.05)$; the rest were less prone to ask about them $(\mathrm{OR}=0.83)$.

\section{Deliberate search for CA in children}

Fifty-six percent of residents deliberately searched for at least one of the forms of CA, and the rest almost never $(40 \%)$ or never (4\%) did. Those who inquired about ACEs in children were identified to also deliberately search for $C A$ twice more often $(O R=1.96)$, in comparison with those who did not inquire the children $(p<0.05)$. The forms that were most frequently sought were PN (42\%), PA (44\%), EA (14\%), SA $(13 \%)$ and EN (8\%).

\section{Barriers for not inquiring about ACEs in clinical practice}

Seventy one percent of participants considered to have barriers (Table 2) to inquire about ACEs; out of them, $5 \%$ did not ask for a history of ACEs in parents and $44 \%$ did not make a deliberate search for CA, a similar proportion ( $46 \%$ ) to that of those who did not report barriers. Lack of simple and practical instruments (questionnaires) to assess the family environment
(40 \%) was considered less as a barrier by females $(p<0.01 ; O R=0.49)$.

\section{Resident physicians' beliefs about ACEs}

Most pediatrics residents stated that TS during childhood can cause DNA epigenetic modifications $(81.7 \%)$, in comparison with subspecialty residents $(14.4 \%, p=0.05)$. Females were less in agreement that TS disrupts brain development and affects school performance $(p=0.01112)$, and that parents who experienced significant ACEs in childhood have more difficulty for establishing stable and supportive relationships $(p<0.001)$.

Those who disagreed with the statements shown in table 3 were more prone not to do a deliberate search for $\mathrm{CA}$ and, regarding the association between the development of diseases and ACEs, more than half mainly associated four out of all seven (Fig. 3).

\section{Mental health training}

Participants who had mental health training performed more deliberate search for CA $(O R=3.3844)$; the fact that $14.3 \%$ rotated in child psychiatry stood out $(\mathrm{OR}=6.9, \mathrm{p}=0.017)$. Those who rotated in behavioral pediatrics asked parents more about a history of ACEs in their childhood ( $p=0.03112$ ).

\section{Discussion}

The results of the present study showed that the participating population had limited knowledge about 
Table 2. Barriers referred by resident physicians for not asking about adverse childhood events $(n=77)$

\begin{tabular}{|c|c|c|c|c|}
\hline Barrier & $\begin{array}{c}\text { Not a } \\
\text { barrier at all } \\
(\%)\end{array}$ & $\begin{array}{c}\text { To a certain point } \\
\text { it is a barrier } \\
(\%)\end{array}$ & $\begin{array}{l}\text { Moderate } \\
\text { barrier } \\
(\%)\end{array}$ & $\begin{array}{l}\text { Significant } \\
\text { barrier } \\
(\%)\end{array}$ \\
\hline $\begin{array}{l}\text { 1. Not fully understanding how genetic predisposition and early childhood } \\
\text { experiences interact to determine behavior and health throughout life. }\end{array}$ & 17 & 44 & 23 & 16 \\
\hline 2. Lack of knowledge about what toxic stress is. & 1 & 23 & 49 & 27 \\
\hline $\begin{array}{l}\text { 3. Lack of simple and practical instruments (questionnaires) to evaluate the } \\
\text { family environment in search of social and emotional risk factors. }{ }^{*}\end{array}$ & 8 & 13 & 39 & 40 \\
\hline $\begin{array}{l}\text { 4. There is no benefit in detecting the social and emotional risk factors that } \\
\text { exist within the family. }\end{array}$ & 22 & 23 & 20 & 35 \\
\hline $\begin{array}{l}\text { 5. Parents are reluctant to discuss social and emotional risk factors that } \\
\text { exist within the family. }\end{array}$ & 3 & 26 & 29 & 42 \\
\hline $\begin{array}{l}\text { 6. Insufficient social programs to address families identified with social and } \\
\text { emotional risk factors. }\end{array}$ & 4 & 19 & 38 & 39 \\
\hline $\begin{array}{l}\text { 7. Lack of coordination to link at-risk families with the resources available in } \\
\text { the community }\end{array}$ & 4 & 18 & 44 & 34 \\
\hline 8. Asking parents about their childhood experiences is uncomfortable. & 17 & 25 & 38 & 20 \\
\hline 9. Unwillingness of parents to talk about their adverse childhood experiences. & 3 & 18 & 44 & 35 \\
\hline $\begin{array}{l}\text { 10. Lack of training in positive parenting techniques that promote healthy } \\
\text { parent-child relationships. }\end{array}$ & 4 & 17 & 48 & 31 \\
\hline $\begin{array}{l}\text { 11. Lack of material (brochures, activities, web-based resources, etc.) to } \\
\text { promote a healthy relationship of parents with their children. }\end{array}$ & 8 & 29 & 38 & 25 \\
\hline $\begin{array}{l}\text { 12. There is no benefit for me in advising parents on a healthy relationship } \\
\text { between them and their children. }\end{array}$ & 38 & 21 & 22 & 19 \\
\hline $\begin{array}{l}\text { 13. I don't have time to advise parents on a healthy relationship between } \\
\text { them and their children. }\end{array}$ & 22 & 23 & 33 & 22 \\
\hline $\begin{array}{l}\text { 14. I don't have time for detecting the social and emotional risk factors that } \\
\text { exist within the family. }\end{array}$ & 22 & 23 & 30 & 25 \\
\hline
\end{tabular}

ACEs, despite the fact that only eleven ${ }^{7-11}$ out of 19 that are currently recognized were addressed. Some participants who had knowledge on the subject named others such as bullying, prolonged hospitalization or death of a family member, and poverty. ${ }^{2,3}$

Poor knowledge about ACEs was also found to be related to a low frequency of inquiring about them or using them in daily practice for deliberate search for $\mathrm{CA}$, which was similar to the results of pediatricians surveyed by the American Academy of Pediatrics. ${ }^{7}$ One cause could be the scarce offer of training on ACEs in medical curricula; ${ }^{12}$ therefore, it is necessary to work on the dissemination of their knowledge, impact and training, since doctors benefit not only because it generates knowledge for them, but also skills and attitudes to inquire about them. ${ }^{13}$ Poor training on
ACEs translates into not being able to address the problem, because there is fear of opening "Pandora's box". ${ }^{14}$ Attention and care skills of physicians has been shown to improve after having been trained on ACEs, as well as the sensitive responses they should have when they listen to patients' testimony. ${ }^{15}$ One proposal is to consider including training on the subject in universities curricula. ${ }^{6,16}$ These initiatives include the optional subject "Child abuse: severity and prevention", which is taught on the Distance Education program of the Faculty of Medicine of the National Autonomous University of Mexico. ${ }^{17}$

Another relevant finding was the limited applicability and usefulness in clinical practice of the knowledge participants had about the effects of TS on brain development, epigenetics and on the development of 
Table 3. Pediatrics resident physicians beliefs about the effect of having adverse childhood experiences (ACEs) and its relationship with deliberate search for child abuse

\begin{tabular}{|c|c|c|c|c|c|}
\hline \multirow[t]{2}{*}{ Belief } & \multirow{2}{*}{$\begin{array}{c}\text { Agree/ } \\
\text { disagree } \\
(\%) \\
(n=77)\end{array}$} & \multicolumn{4}{|c|}{ Deliberate search for CA (\%) } \\
\hline & & $\begin{array}{l}\text { Do not } \\
\text { investigate } \\
(n=34)\end{array}$ & $\begin{array}{l}\text { Do } \\
\text { investigate } \\
(n=43)\end{array}$ & $\mathbf{p}^{*}$ & OR \\
\hline $\begin{array}{l}\text { 1. Prolonged or excessive physiological stress during childhood can cause } \\
\text { epigenetic DNA modifications. } \\
\text { Agree } \\
\text { Disagree }\end{array}$ & $\begin{array}{c}96.1 \\
3.9\end{array}$ & $\begin{array}{l}41.9 \\
100\end{array}$ & $\begin{array}{c}58.1 \\
0\end{array}$ & 0.05 & 9.66 \\
\hline $\begin{array}{l}\text { 2. Prolonged or excessive physiological stress during childhood can disrupt } \\
\text { brain development and affect school performance. } \\
\text { Agree } \\
\text { Disagree }\end{array}$ & $\begin{array}{c}98.7 \\
1.3\end{array}$ & $\begin{array}{c}43.22 \\
100\end{array}$ & $\begin{array}{c}56.78 \\
0\end{array}$ & 0.05 & 3.89 \\
\hline $\begin{array}{l}\text { 3. Persistent physiological stress during childhood can cause for children to be } \\
\text { less able to handle stress in their future life. } \\
\text { Agree } \\
\text { Disagree }\end{array}$ & $\begin{array}{c}100 \\
0\end{array}$ & $\begin{array}{c}44.15 \\
0\end{array}$ & $\begin{array}{c}55.85 \\
0\end{array}$ & - & \\
\hline $\begin{array}{l}\text { 4. Brief periods of stress can positively influence on children by promoting } \\
\text { adaptability. } \\
\text { Agree } \\
\text { Disagree }\end{array}$ & $\begin{array}{c}93.5 \\
6.5\end{array}$ & $\begin{array}{c}41.67 \\
80\end{array}$ & $\begin{array}{c}58.33 \\
20\end{array}$ & 0.19 & \\
\hline $\begin{array}{l}\text { 5. Detecting socio-emotional risk factors within the family (e.g., depression, } \\
\text { parental substance abuse, domestic violence, etc.) is beyond the scope of } \\
\text { pediatric medicine. } \\
\text { Agree } \\
\text { Disagree }\end{array}$ & $\begin{array}{l}53.24 \\
46.75\end{array}$ & $\begin{array}{l}48.79 \\
38.39\end{array}$ & $\begin{array}{l}51.21 \\
61.11\end{array}$ & 0.36 & \\
\hline $\begin{array}{l}\text { 6. Stable and supportive relationships can mitigate the negative effects of } \\
\text { persistent stress during childhood. } \\
\text { Agree } \\
\text { Disagree }\end{array}$ & $\begin{array}{c}100 \\
0\end{array}$ & $\begin{array}{c}44.15 \\
0\end{array}$ & $\begin{array}{c}55.85 \\
0\end{array}$ & - & \\
\hline $\begin{array}{l}\text { 7. Parents who have experienced significant ACEs during childhood have more } \\
\text { difficulty to establish stable and supportive relationships with their children in } \\
\text { comparison with those who did not experience them. } \\
\text { Agree } \\
\text { Disagree }\end{array}$ & $\begin{array}{c}93.5 \\
6.5\end{array}$ & $\begin{array}{c}46.76 \\
60\end{array}$ & $\begin{array}{c}53.24 \\
40\end{array}$ & 0.04 & 1.98 \\
\hline $\begin{array}{l}\text { 8. Pediatrician's advice has little effect for improving parents' skills in positive } \\
\text { parenting of their children. } \\
\text { Agree } \\
\text { Disagree }\end{array}$ & $\begin{array}{l}51.95 \\
48.05\end{array}$ & $\begin{array}{c}40 \\
48.64\end{array}$ & $\begin{array}{c}60 \\
51.36\end{array}$ & 0.35 & \\
\hline
\end{tabular}

diseases in the medium and long term, because, although they knew about them, less than half inquired about the ACEs that caused them and considered them barriers or did not agree on the benefit of interventions or the role of the pediatrician to prevent their effects, as it has been observed in other studies with resident physicians. ${ }^{18}$

Half the participants had the perception or belief that it is beyond the pediatrician's reach to identify socio-emotional risk factors in families, as well as their possible intervention to mitigate their negative effects. ${ }^{14}$ Such perception has no grounds, since between 50 and $85 \%$ of parents or caregivers have been described to expect their children's pediatricians to ask about these situations. When a serious situation or an important family concern manifests itself, parents consider pediatricians as one of the first sources of help to resort to. ${ }^{19}$

It appers that it is not clear for pediatricians in training that they are in a privileged position by holding in their hands a means to transmit and influence on the health of a child. ${ }^{19,20}$ In addition, they have the possibility to collaborate with social workers, organizations and the State in order for the required laws and 


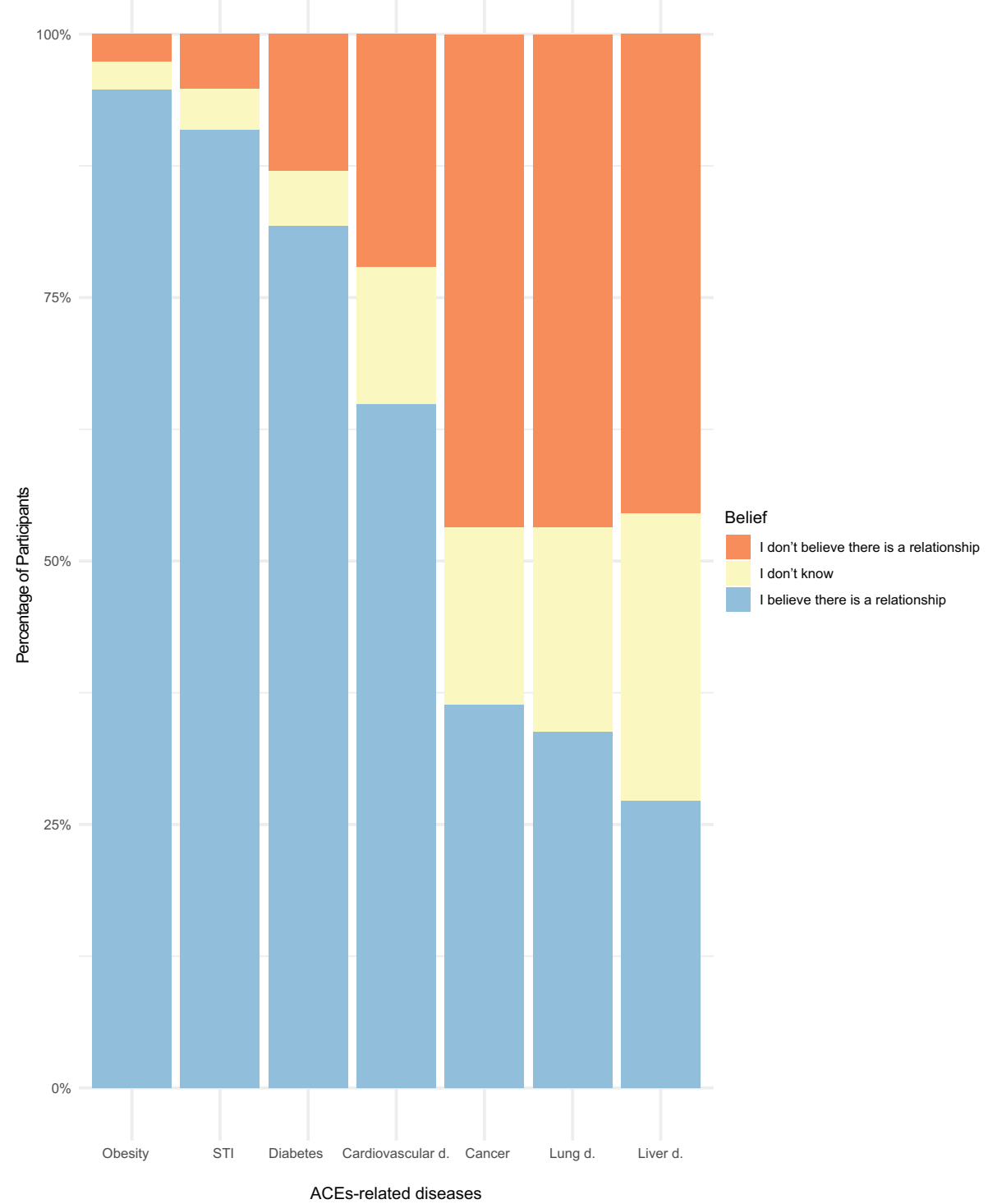

Figure 3. Resident physicians beliefs about the relationship between adverse childhood experiences (ACES) and the development of diseases in the long-term. $d$ = disease; $S T I=$ sexually-transmitted infection; ACEs = adverse childhood experiences.

changes to be applied. ${ }^{5,20}$ Health and well-being of children will inevitably depend on the physical, emotional and social status of their parents and on the social circumstances and the care they receive. ACEs evaluation, together with development and behavior, might help to timely identify risk behaviors and children who are prone to develop mental health problems or related diseases, as well as to prevent intergenerational transmission. ${ }^{21}$

The main barriers to inquiring about ACEs referred by participants, as in other studies, were related to the discomfort of asking about these issues, lack of simple questionnaires to identify at-risk families, lack of time and lack of connection with social services and programs that can address these needs. ${ }^{22}$ Possible solutions to said barriers include the following:

- Training on $\mathrm{ACEs}^{23}$ and management of patient consultation time. ${ }^{14}$

- Having easy-to-apply questionnaires, a situation we are currently working in to address this need.

- Generating and publicizing directories of support networks, programs and available channeling services, in order to make the most of those community and civil society resources that are already available. ${ }^{23}$

Regarding the study limitations, the response rate was suboptimal, a situation that also occurred in the American Academy of Pediatrics survey, ${ }^{7}$ which obtained a response rate of $37 \%$. This could be related 
to the low interest of physicians for participating in surveys sent by electronic means. ${ }^{24}$ Another limitation of this study is non-response bias, and that the results cannot be generalized to the entire population of residents of the Institute, although it provided valuable information on the situation of knowledge and use of ACEs to make suggestions on the subject. ${ }^{24}$

\section{Acknowledgements}

To Dr. José Nicolás Reynés Manzur, Teaching Director, for the help provided to carry out the study; as well as to Dr. Silvestre García de la Puente, for methodological advice.

\section{Conflicts of interest}

None.

\section{Funding}

This research received financial funding from Instituto Nacional de Pediatría, through the Fondo de Recurso Fiscal para Investigación E022-2018 program.

\section{Ethical disclosures}

Protection of human and animal subjects. The authors declare that the procedures that were followed adhered to the ethical standards of the responsible committee for experimentation on human beings and were in agreement with the World Medical Association and the Declaration of Helsinki.

Confidentiality of data. The authors declare that no patient data appear in this article.

Right to privacy and informed consent. The authors declare that no patient data appear in this article.

\section{References}

1. Holman DM, Ports KA, Buchanan ND, Hawkins NA, Merrick MT Metzler M, et al. The association between adverse childhood experiences and risk of cancer in adulthood: a systematic review of the literature. Pediatrics. 2016;138:S81-S91.
2. Finkelhor D, Shattuck A, Turner $H$, Hamby S. Improving the adverse childhood experiences study scale. JAMA Pediatr. 2013;167:70-75.

3. Cronholm PF, Forke CM, Wade R, Bair-Merritt MH, Davis M, Harkins-Schwarz $M$, et al. Adverse childhood experiences: expanding the concept of adversity. Am J Prev Med. 2015;49:354-361.

4. Boullier M, Blair M. Adverse childhood experiences. Paediatr Child Heal (United Kingdom). 2018:28:132-137.

5. American Academy of Pediatrics. Early childhood adversity, toxic stress, and the role of the pediatrician: translating developmental science into lifelong health. Pediatrics. 2012;129:e224-e231.

6. Shonkoff JP, Committee on Psycholosocial Aspects of Child and Familiy Health, Committee on Early Childhood, Adoption, and Dependent Care A, Section on Developmental and Behavioral Pediatrics. The lifelong effects of early childhood adversity and toxic stress. Pediatrics. 2012;129:e232-e246.

7. Kerker BD, Storfer-Isser A, Szilagyi M, Stein REK, Garner AS, O'Connor KG, et al. Do pediatricians ask about adverse childhood experiences in pediatric primary care? Acad Pediatr. 2016;16(2):154-160.

8. Lipsitz SR, Fitzmaurice GM, Sinha D, Hevelone N, Giovannucci E, $\mathrm{Hu}$ JC. Testing for independence in JxK contingency tables with complex sample survey data. Biometrics. 2015;71:832-840.

9. Williams R. Analyzing rare events with logistic regression. France: University of Notre Dame [Internet]; 2019.

10. R: a language and envrionment for statistical computing [Internet]. Austria: R Foundation for Statistical Computing; 2019

11. Felitti VJ, Anda RF, Nordenberg D, Williamson DF, Spitz AM, Edwards V, et al. Relationship of childhood abuse and household dysfunction to many of the leading causes of death in adults. The Adverse Childhood Experiences (ACE) Study. Am J Prev Med. 1992;14:245-258.

12. Pletcher BA, O'Connor M, Swift-Taylor ME, DallaPiazza M. Adverse childhood experiences: a case-based workshop introducing medical students to trauma-informed care. MedEdPORTAL. 2019;15:1-8.

13. Alexander RC. Education of the physician in child abuse. Pediatr Clin North Am. 2016;37:971-988.

14. Wen FK, Miller-Cribbs JE, Coon KA, Jelley MJ, Foulks-Rodríguez KA. A simulation and video-based training program to address adverse childhood experiences. Int J Psychiatry Med. 2017;52:255-264.

15. Magen E, DeLisser HM. Best practices in relational skills training for medical trainees and providers: an essential element of addressing adverse childhood experiences and promoting resilience. Acad Pediatr. 2017:17:S102-S107.

16. Bethell CD, Solloway MR, Guinosso S, Hassink S, Srivastav A, Ford D, et al. Prioritizing possibilities for child and family health: an agenda to address adverse childhood experiences and foster the social and emotional roots of well-being in pediatrics. Acad Pediatr. 2017; 17:S36-S50.

17. Universidad Nacional Atónoma de México/Secretaría Sistemas Universidad Abierta y Educación a Distancia/Facultad de Medicina [Internet]. Mexico: Licenciatura de médico cirujano; 2019.

18. Tink W, Tink JC, Turin TC, Kelly M. Adverse childhood experiences: Survey of resident practice, knowledge, and attitude. Fam Med. 2017;49:7-13

19. Hassink SG. Reclaiming the patient encounter. Acad Pediatr. 2017;17:S12-S13.

20. Garner AS, Forkey H, Szilagyi M. Translating developmental science to address childhood adversity. Acad Pediatr. 2015;15:493-502.

21. Marie-Mitchell A, Studer KR, O'Connor TG. How knowledge of adverse childhood experiences can help pediatricians prevent mental health problems. Fam Syst Heal. 2016;34:128-135.

22. Szilagyi M, Kerker BD, Storfer-Isser A, Stein REK, Garner A, O'Connor KG et al. Factors associated with whether pediatricians inquire about parents' adverse childhood experiences. Acad Pediatr. 2016;16:668-675.

23. Jacob G, van den Heuvel M, Jama N, Moore AM, Ford-Jones L, Wong P. Adverse childhood experiences: basics for the paediatrician. Paediatr Child Health. 2018;24:30-37.

24. Nicholls K, Chapman K, Shaw T, Perkins A, Sullivan MM, Crutchfield S, et al. Enhancing response rates in physician surveys: the limited utility of electronic options. Health Serv Res. 2011;46:1675-1682. 